\title{
Language and Political Psychology: Can Grammar Influence Electability?
}

\author{
Debbita Tan Ai Lin \\ debbitatan@usm.my \\ School of Languages, Literacies and Translation, \\ Universiti Sains Malaysia
}

\begin{abstract}
Daily, the public is plied with political messages from various sources and millions are invested in campaign ads each election year. Yet, surprisingly little is known about the influence of linguistic details in such messages on attitudes about political candidates, especially within the context of Malaysia. The present study is grounded within the structure of framing and grammar, and suggests that grammar can influence attitudes towards a candidate's electability. The study involved 387 male and female Malaysian university students (19- to 25-year-olds) of various ethnicities. The researcher designed two comprehensive questionnaires based on Fausey and Matlock's (2011) work. Participants were randomly assigned Version A $(n=192)$ or Version B $(n=195)$ of the questionnaire. Both versions were about the conduct of Members of Parliament, unnamed and without party labels, to avoid bias about actual politicians. The conduct or actions were of negative and positive valence; Version A was framed using the imperfective form ['was verb + ing'] and employed the modal verb 'must', whereas Version B was framed using the perfective form ['verb + ed'] and employed the modal verb 'have to'. Primarily, results revealed that imperfective descriptions of negative actions resulted in negative responses to the re-election of a candidate. However, the participants were largely insensitive to grammatical alteration when judging a candidate's past positive actions. The results on modality demonstrated a preference for the modal verb 'must' which carries more "emotional value" than 'have to'. The present study is novel in that it covers the dimension of modality (which has never been explored in previous studies) and that to date, there is no available research similar to it in the Malaysian context.
\end{abstract}

Keywords: framing; political communication; grammar; electability; psycholinguistics

\section{INTRODUCTION AND RATIONALE FOR THE STUDY}

According to Matlock (2012), "how something is said may be as important as what is said" (p. 478). Matlock elaborated that in an election year, voters are plied with political messages from numerous sources, including television advertisements, campaign websites, blogs and social media platforms such as Facebook. These messages concentrate on a range of issues, from the candidate's stand on different social issues to his or her personality and even their past actions - some of which may be true or factual and objectively presented, and others less so.

So, does it matter how a political message is constructed? In other words, can grammar really win elections? Time and again, we have witnessed the employment of various linguistic devices in political messages - by campaign writers, journalists, and even politicians themselves - to various degrees. Al-Rikaby, Tengku Mahadi, and Tan (2018, p. 300) highlighted the following in their research on political speech titles:

Political leaders, as writers, differ as to what form and in what manner a message should be revealed. Some employ the use of catchy titles which are usually short, rhythmical and alliterative, while others prefer using titles full of puns, literary allusions and other 
obscurities. A third group may prefer clichés, superlatives, stock phrases and vague generalizations.

Linguists and political scientists such as Teenie Matlock, Caitlin Fausey and James Druckman study language and politics, and more specifically, how political messages influence voters. Their work demonstrates that an individual can be influenced by "framing, how a message is worded to encourage particular interpretations and inferences" (Matlock, 2012, p. 478). According to Matlock (2012), negative framing is often used to portray a candidate as weak, immoral and incompetent, and can be effective even when subtle. She elaborated that negative framing is persuasive because it can capture attention and create anxiety about future repercussions. On the other side of the spectrum would be positive framing and this may be adequately illustrated by Fountaine's (2017) recent study concerning two politicians' self-framing on Twitter. Fountaine found that a likability frame dominated their messaging, supported by subsidiary frames of 'the busy local MP' and 'the relational politician'. The codes or elements encompassed in the metaframe of likability included humour, flattery, acknowledgement of others, empathy and sympathy, and low levels of conflict and negativity. Both politicians, Nikki Kaye and Jacinda Ardern, were returned to the New Zealand Parliament.

In sum, language can potentially affect opinions or attitudes, and admittedly, one would most likely be less confident of the re-election of a candidate described as having a past history of accepting bribes or of drug abuse. What is interesting here, however, is how language has this effect or influence, within the context of framing. It is particularly interesting to discover how the subtleties of grammar might play a role in voter persuasion, especially since millions are invested in campaign ads each election year.

Furthermore, aside from the motivation of research interest, a paucity of available studies of this nature plays a part in the rationale for this study. Matters are improving, however, with framing effects receiving increased interest by demonstrating their potential with regards to influencing opinions or attitudes among citizens and affecting how people think about issues (Mannetti, Brizi, Giacomantonio, \& Higgins, 2013). Despite this, it is an area that can still benefit from an extension of its knowledge base as it remains a domain not yet widely researched, especially within a context involving young Malaysians. Fausey and Matlock (2011) highlighted that surprisingly little is known about the influence of linguistic details in political messages on attitudes about political candidates and whether they will be elected.

The present study involved university students within the age group of 19 to 25 years old - essentially, individuals who were either of voting age already or will be of voting age in the 15th Malaysian General Election. The 14th Malaysian General Election was held in May of 2018 and ousted the Barisan Nasional coalition that had ruled the nation for six decades, and put in power Pakatan Harapan - led by Tun Mahathir Mohamad, now 94, who had before served as the Prime Minister of Malaysia for 22 years from 1981. This study addresses this research question: To what extent does grammar influence Malaysian university students' attitudes towards a political candidate's electability?

The following table (Table 1) presents the operationalisation of the primary terms or elements of the research question. This is to achieve better concretisation of the important terms or elements specific to this study. It is also intended to more clearly demarcate the scope of the study. More comprehensive details are provided in the subsequent sections. 


\begin{tabular}{|c|c|}
\hline Terms & Operationalisation \\
\hline Grammar & $\begin{array}{l}\text { English language grammar, comparing between: } \\
\text { (a) Imperfective Aspectual Marker ['was verb }+ \text { ing'] and } \\
\text { Perfective Aspectual Marker ['verb }+e d \text { '] } \\
\text { (b) Obligation Modal Verb 'must' and } \\
\text { Obligation Modal Verb 'have to' }\end{array}$ \\
\hline $\begin{array}{l}\text { Malaysian university } \\
\text { students }\end{array}$ & $\begin{array}{l}\text { (a) Male and female undergraduate students of Malaysian nationality enrolled } \\
\text { in a public university in Malaysia, within the age group of } 19 \text { to } 25 \text { years } \\
\text { old, and largely of intermediate to higher intermediate English language } \\
\text { ability } \\
\text { (b) Primarily composed of Malays, Chinese and Indians from urban and sub- } \\
\text { urban hometowns }\end{array}$ \\
\hline Attitudes & Point of view or position \\
\hline Political candidate & $\begin{array}{l}\text { Unnamed Member of Parliament without party label (to avoid bias about actual } \\
\text { politicians) }\end{array}$ \\
\hline Electability & Capability or possession of a reasonable chance to be elected to public office \\
\hline
\end{tabular}

\section{RELATED LITERATURE}

\section{THE MALAYSIAN ELECTORAL BACKGROUND}

Malaysia is a constitutional monarchy employing "a Westminster-style parliamentary system inherited from the British" (Ostwald, 2017, p. 3). The federal parliament is bicameral, comprising an appointed senate (Dewan Negara) and an elected Dewan Rakyat, the lower house of Parliament. The Dewan Rakyat has 222 seats, a substantial increase from the 98 at the time of the first general election (Ostwald, 2017).

Elections in Malaysia exist at two levels - federal and state. Federal elections are for membership in the Dewan Rakyat and state elections are for membership in the State Legislative Assemblies. The Constitution of Malaysia requires that a general election be held at least once every five years. Elections are supervised by the Election Commission and the campaign period permitted by law runs from the date of nomination day. The minimum campaign period is presently eleven days (Ostwald, ibid.).

The voting age in Malaysia is 21 years old and only registered voters may vote in the general elections. The country's population, in terms of racial composition, is diverse; the nation is made up of Malays (55\%), Chinese (23\%), Indians (7\%) and others (15\%) (Ostwald, ibid.). According to a report by Bernama (April 2018), Malaysia's national news agency, at the fourth quarter of 2017, the EC had 14,968,304 registered voters in its electoral roll. Women constituted 7.5 million (50.6\%) of registered voters and men, 7.3 million (49.9\%). From the total, 6.2 million were in the 21 to 39 years old age group.

It is also noteworthy that English is Malaysia's second language (English was accorded the status when the National Language Policy was implemented in 1970) and Malaysians are required to learn the language in formal schooling, starting from the primary level. In most public universities, undergraduates must also undergo and pass a certain number of English proficiency courses in order to graduate. Furthermore, in their study on the 2013 Malaysian General Election, Kasim and Mohd Sani (2016) pointed out that The Star Online, a local English news portal, was actually the most popular news portal in the country.

As underscored by Matlock (2012), voters are often inundated with political messages from different sources during elections, including online sources, and it is not surprising that 
the language used in these messages can have an impact on voters' attitudes about political candidates. Now, more than ever, lies the significance of language in political messages; populations are becoming more aware of their political landscape as news and information become increasingly more accessible to all the strata of society, particularly young voters, due to the force of technology. Kasim and Mohd Sani (2016), in their work on the 2013 general elections in Malaysia, singled out the Internet and remarked that "The Internet has become the battleground for the domination of public opinion" (p. 121).

\section{FRAMING AND THE MIND}

The term 'framing' itself is multifarious with regards to its definition. It is a concept widely applied in a generous array of disciplines, although the term was first coined by Frederic Bartlett in the field of cognitive psychology (Pluwak, 2011). Fountaine (2017) described framing as a concept concerned with message content, and as one that is widely utilised in the social sciences and humanities. Additionally, Fountaine stressed that framing is chiefly a message production process and that framing sets the tone for individual interpretation.

Framing is, broadly, a flexible entity. Pluwak (2011), in her work on the linguistic aspects of framing in modern political campaigns, described it as a "very general mechanism" (p. 308) applicable to both visual and textual contents. She opined that properly chosen wording or framing in political messages can have implications with respect to influencing public opinions and preferences.

In the psychological sense, framing is a phenomenon relating to stimuli and categorisation. For instance, new information received is classified or treated according to previously acquired knowledge and experiences (Lakoff \& Johnson, 1999). Within the context of linguistics and political framing, Lakoff $(2002,2004)$ distinguished between deep framing and surface framing. The former refers to the activation of cognitive structures while the latter corresponds with the linguistic aspects applied. Lakoff (2004) posited that once language is adopted, the knowledge and values behind a particular word fashion our approach and attitudes towards the issue at hand. Hence, a word can achieve more than merely a plain or literal interpretation.

Nobel Prize winner Daniel Kahneman and his collaborator Amos Tversky led the way in terms of research on framing. Their work on rationality demonstrated that we are actually consistently irrational, a state which can leave us surprisingly susceptible to the wiles and powers of framing. Tversky and Kahneman (1986) put forth that despite a priori arguments in favour of rational choice, "deviations of actual behavior from the normative model are too widespread to be ignored, too systematic to be dismissed as random error" (p. 252). They instead showed us that we rely on mental shortcuts to speed up our reasoning and that even the most essential and obvious principles of rational choice - dominance and invariance - are only obeyed in transparent applications, and are often violated in other conditions. Dominance refers to logical choice; if Option A is better than Option B in one state and is at least as good in all other possible states, then Option A should be chosen. Invariance, meanwhile, adheres to the normative status, whereby varied representations of the same choice problem should yield the same preference. In essence, if variations of Element X (e.g., $\left.\mathrm{X}^{1}, \mathrm{X}^{2}, \mathrm{X}^{3}\right)$ do not have an actual effect on the outcomes, then they should also not affect the choice. This has been upended by McNeil et al. (1982) study on medical treatment preferences. Their respondents were presented with the following information, as cited in Tversky and Kahneman (1986): 


\section{Problem 1 (Survival frame)}

Surgery: Of 100 people having surgery 90 live through the post-operative period, 68 are alive at the end of the first year and 34 are alive at the end of five years.

Radiation Therapy: Of 100 people having radiation therapy all live through the treatment, 77 are alive at the end of one year and 22 are alive at the end of five years.

\section{Problem 1 (Mortality frame)}

Surgery: Of 100 people having surgery 10 die during surgery or the postoperative period, 32 die by the end of the first year and 66 die by the end of five years.

Radiation Therapy: Of 100 people having radiation therapy, none die during treatment, 23 die by the end of one year and 78 die by the end of five years.

Despite the minute disparity, a marked effect was observed. According to McNeil et al. (1982), the most notable finding was the effect of terminology on choices - surgery seemed to be much more attractive when the outcomes were framed in terms of survival rather than in terms of death. Also, interestingly, the effect was not smaller for physicians (termed as 'sophisticated subjects') and business students with statistical knowledge than for patients (termed as 'naive subjects').

Fundamentally, one can indeed argue that we are sensitive to framing. After all, although we have yet to reach a solid consensus, studies do suggest that linguistic manipulation can result in cognitive illusions and consequently covertly influence our judgments and behaviours. Indeed, it has been found that a simple alteration of words, from 'beast preying' to 'virus infecting', can have a remarkable effect on people's beliefs about crime (Thibodeau \& Boroditsky, 2011).

\section{FRAMING WITH GRAMMAR}

According to Fausey and Matlock (2011), the wording of political messages is known to affect voting attitudes, which include judgments as to whether a political candidate will be elected to office. What is intriguing to us, however, is whether voting attitudes can be impacted or influenced by the subtleties of grammar. In other words, can individuals be influenced by "the fine-grained grammatical details" (p. 563) embedded in the political messages made available to the masses?

The present study demonstrates that altering grammatical information can result in different attitudes regarding electability. As with Fausey and Matlock's (2011) research, the present study focused on the use of imperfective and perfective aspectual markers. This study also extended its focus to the obligation modal verbs 'must' and 'have to'. To the researcher's knowledge, at the time of writing, there is no available research similar to the current work that also include modal verbs.

In terms of English grammar for past events, imperfective aspectual markers ['was verb + ing'] emphasise the ongoing nature of actions, and perfective aspectual markers ['verb $\left.+e d^{\prime}\right]$ emphasise the completion or end state of actions (Fausey \& Matlock, ibid.; Madden \& Zwaan, 2003). Essentially, we can describe past events in different ways when it comes to the English language, but there is the matter of conceptualisation. Matlock (2012) presented the following example:

\section{Sentence 1 Maria was riding her bike last night. \\ Sentence 2 Maria rode her bike last night.}


She explained that both statements are perfectly acceptable and express the same event. However, she noted that there is a difference in how the action is construed. With the first sentence, the event is conceptualised as ongoing with the use of the past progressive grammatical form ['was verb + ing'] whereas with the second sentence, the event is conceptualised as a completed event with the use of the simple past grammatical form ['verb $+e d^{\prime}$ ']. Matlock (ibid., pp. 478-479) observed the following, with regards to this distinction in conceptualisation:

"This distinction is common across languages, even though it is realized in different ways. For instance, Russian has a more complex, nuanced aspectual system than English does."

The present study is also concerned with the modal verbs 'must' and 'have to'. Fundamentally, modal verbs are used to indicate modality, for instance, permission, ability, likelihood, possibility, and inevitability. According to Kakzhanova (2013), modals are complex. In tandem with Palmer (1990), Kakzhanova described modals as a complicated grammatical phenomenon, with its standing still not precisely defined in the literature of linguistics. In terms of the function of modals, she pointed out that just as articles determine whether nouns are definite or indefinite, modals serve to "determine the relation of a person to actions or the quality of an action as realizable or unrealizable" (p. 2530).

Elaborating on the complexity of modals, Imre (2017) argued that the modal verb 'will' is neither the 'future auxiliary' nor the 'conditional auxiliary'; instead, the modal verb the core meaning of the modal verb 'will' is linked to the concept of inevitability. With respect to conceptualisation and its relevance to the current study, 'must' and 'have to' are essentially obligation modal verbs. Each, however, embodies its own subtle shade of conceptualisation under this structure.

Grammatically, 'must' and 'have to' are employed in expressions of obligation and can often be used interchangeably in English. The difference between the two lies within a context that is better described as emotional rather than structural. Largely, 'must' implies that the obligation to do something comes directly from the speaker while 'have to' implies that the obligation comes from another person or that the obligation is imposed externally; this in turn conveys the sense or notion that 'must' expresses the speaker's feelings and is more personal, whereas 'have to' expresses a more impersonal and detached idea. As mentioned, to the researcher's knowledge, this is a research gap that has yet to be filled and as such, the present study was designed to investigate if this nuance can influence attitudes towards a political candidate's electability.

Grammar and the framing of political messages is presently an understudied area, although the relatively few available studies have largely demonstrated a reciprocal relationship between the wording of political messages and attitudes regarding electability. This is an area worthy of further and more encompassing research, as grammatical information may well have implications of import in terms of how the masses perceive political candidates vying for public office is a likely predictor of election outcomes.

\section{SIMILAR PAST STUDIES}

In July 2016, George Lakoff, Distinguished Professor of Cognitive Science and Linguistics Emeritus at the University of California at Berkeley, wrote an article detailing how Donald Trump uses your brain to his advantage. According to Lakoff, among the mechanisms that Trump uses are: 


\section{Repetition}

Example: Win. Win, Win. We're gonna win so much you'll get tired of winning.

Lakoff explained that words are neurally linked to the circuits that determine their meaning and the more a particular word is heard, the more the circuits get activated and grow stronger.

2. Grammar

\section{Example: Radical Islamic terrorists}

The word 'radical' places Muslims on a linear scale and the word 'terrorists' imposes a frame on this scale, suggesting that terrorism is embodied in Islam.

3. Metaphor

\section{Example: Make America Great Again}

Conventional metaphorical thought is inherent in our mind and we normally do not explicitly notice such thoughts. The universal metaphor that states are locations in space allows us to believe that we can enter a state, exit that state, and be back at where we were; Trump's metaphor of making America great again implies a notion of some past ideal state that Americans can return to just by making Trump president.

In pointing out these mechanisms, Lakoff is in sync with extant literature on the effects of linguistic manipulation in real-world domains. In five experiments, Thibodeau and Boroditsky (2011) observed the role of metaphor in reasoning and concluded that metaphors have a substantial influence on how we conceptualise and act with respect to societal issues. They specifically investigated the issue of crime and found that even the most delicate instantiation of a metaphor can affect how people attempt to solve problems and how they make decisions. They also discovered that self-identified Republicans were less likely to be influenced by the metaphors presented than were Democrats and Independents. The research involved university students as well as participants from various sub-populations recruited online, and presented crime as either a beast or a virus. For example:

\footnotetext{
"Crime is a \{wild beast preying on/virus infecting\} the city of Addison. The crime rate in the once peaceful city has steadily increased over the past three years. In fact, these days it seems that crime is \{lurking in/plaguing \} every neighborhood. In 2004, 46,177 crimes were reported compared to more than 55,000 reported in 2007. The rise in violent crime is particularly alarming. In 2004, there were 330 murders in the city, in 2007, there were over 500."

(p. 3)
}

The participants were asked to respond to two questions after reading the text. It was found that those who read that crime was a beast tended to suggest fighting back by hiring police officers and building jails. Incongruently, those who read that crime was a virus tended to suggest treating the problem by examining the root cause and implementing social reforms. Both groups generally identified the crime statistics - and not the metaphor - as the most influential dimension of the text, suggesting metaphorical elements to be covert agents rather than explicit ones.

Meanwhile, Fausey and Matlock (2011), in their study on grammar and elections, proposed the plausibility of language shaping thought and influencing electability. The study comprised two conditions, both of which involved a fictitious politician:

\section{Condition/Study 1}

Senator Mark Johnson had done either negative or positive actions and these were described using the imperfective aspect ['verb + ing'] or the perfective aspect ['verb $+e d^{\prime}$ ']. 


\section{Condition/Study 2}

Senator Mark Johnson had done a negative action and a positive action, one of which was described using the imperfective aspect and another using the perfective aspect.

\begin{tabular}{|c|c|c|}
\hline \multicolumn{3}{|c|}{ Study 1 Stimuli. } \\
\hline \multirow{2}{*}{$\begin{array}{l}\text { Action } \\
\text { valence }\end{array}$} & \multicolumn{2}{|c|}{ Grammatical form } \\
\hline & Perfective $($ verb $+e d)$ & Imperfective (was verb + ing) \\
\hline Negative & $\begin{array}{l}\text { Mark Johnson is a Senator in the United } \\
\text { States Senate. He is up for reelection. He } \\
\text { graduated from the University of Texas, } \\
\text { Austin with a degree in political science. } \\
\text { Mark's first term as a United States } \\
\text { Senator is almost complete. Last year, } \\
\text { Mark had an affair with his assistant } \\
\text { and took hush monev from a } \\
\text { prominent constituent. }(N=92)\end{array}$ & $\begin{array}{l}\text { Mark Johnson is a Senator in the United } \\
\text { States Senate. He is up for reelection. He } \\
\text { graduated from the University of Texas, } \\
\text { Austin with a degree in political science. } \\
\text { Mark's first term as a United States } \\
\text { Senator is almost complete. Last year, } \\
\text { Mark was having an affair with his } \\
\text { assistant and was taking hush money } \\
\text { from a prominent constituent. }(N=96)\end{array}$ \\
\hline Positive & $\begin{array}{l}\text { Mark Johnson is a Senator in the United } \\
\text { States Senate. He is up for reelection. He } \\
\text { graduated from the University of Texas, } \\
\text { Austin with a degree in political science. } \\
\text { Mark's first term as a United States } \\
\text { Senator is almost complete. Last year, } \\
\text { Mark rekindled his relationship with his } \\
\text { wife and collected donation money } \\
\text { for the American Cancer Society. }(N=85)\end{array}$ & $\begin{array}{l}\text { Mark Johnson is a Senator in the United } \\
\text { States Senate. He is up for reelection. He } \\
\text { graduated from the University of Texas, } \\
\text { Austin with a degree in political science. } \\
\text { Mark's first term as a United States } \\
\text { Senator is almost complete. Last year, } \\
\text { Mark was rekindling his relationship with } \\
\text { his wife and was collecting donation money } \\
\text { for the American Cancer Society. }(N=81)\end{array}$ \\
\hline \multicolumn{3}{|c|}{ Study 2 Stimuli. } \\
\hline \multicolumn{3}{|c|}{$\begin{array}{l}\text { Mark Johnson is a Senator in the United States Senate. He is up for reelection. Last year, his } \\
\text { district faced rush hour traffic problems. Under eminent domain Mark was removing homes and } \\
\text { extended roads in his district. Traffic conditions improved. }(\mathrm{N}=58)\end{array}$} \\
\hline \multicolumn{3}{|c|}{$\begin{array}{l}\text { Mark Johnson is a Senator in the United States Senate. He is up for reelection. Last year, his } \\
\text { district faced rush hour traffic problems. Under eminent domain Mark removed homes and was } \\
\text { extending roads in his district. Traffic conditions improved. }(\mathrm{N}=62)\end{array}$} \\
\hline
\end{tabular}

FIGURE 1. Condition/Study Stimuli 1 and 2 (Fausey \& Matlock, ibid.)

354 undergraduates of the University of California, Merced, took part in Study 1 and answered questions on a 7-point scale (post-exposure to stimuli). The researchers found that the participants were more confident in voting not to re-elect a politician who was doing negative actions as compared to one who did negative actions, inferring that more immoral action was thought to be involved when the past event was described using the imperfective aspect in comparison to the perfective aspect.

Study 2 involved 127 participants from Stanford University who answered the same questions post-exposure to stimuli regarding Senator Mark Johnson's eminent domain policy. It was found that grammatical information can be an implicit agent in influencing attitudes towards electability. Bias was evident due to the use of the imperfective aspect; electability decreased when the negative outcome of Johnson's policy was described using the imperfective aspect. The researchers concluded that voters appear to be sensitive to subtle linguistic details when making judgments about political candidates, and recommended that future research is necessary for us to achieve a fuller understanding of the impact of language 
in the world of politics. The examination of other grammatical features in political messages is also suggested.

Congruent with the aspect of past progressive and simple past framings, Matlock et al. (2012) conducted a study on how people describe car accidents and arrived at patterns supportive of Fausey and Matlock's (2011) findings. Matlock et al. (2012) screened six videos of vehicle collisions to their participants and after each video, one group was prompted with "Tell what was happening" while another group was prompted with "Tell what happened". It was observed that a slight grammatical adjustment in the prompts resulted in quite a difference, with the former group including more motion verbs and reckless driving phrases in their descriptions. The researchers advanced that tweaking grammatical aspects can cause differences in thinking; imperfective framing appears to trigger the encoding of more action per situation than perfective framing. In short, people tend to replay in their mind richer and more vivid action details, which might not bode well at all for an ambitious politician accused of adultery in the past progressive tense.

As mentioned earlier, research on how the subtleties of grammar might play a role in voter persuasion remains a domain not yet adequately explored (especially within a context involving Malaysians). There is, however, another side of the field worthy of note to furnish us with a more balanced picture, one that proffers some insight into the preferred linguistic devices of politicians themselves. Hanks (1996) proposed that linguistic constructions do convey a certain imagination of socially engaged entities. Therefore politicians would do well, perhaps, to utilise such constructions for their own gains.

Allen (2007) highlighted that in their speeches, politicians tend to present two things their positive aspects and their opponents' negative aspects. One way of executing this is by the intentional use of specific pronouns. This is in tandem with Bramley (2001) who, in her study on Australian political discourse, demonstrated how politicians actively exploit the flexibility of pronominal reference to build a representation of themselves and of others that is ultimately favourable to their own image. Additionally, in her study on Hillary Clinton and Donald Trump, Alavidze (2017) offered the following summary concerning pronominal reference in political discourse:

1. 'I' implies a personal level, making it possible for the speaker to show authority and personal responsibility, as well as commitment and involvement;

2. 'We' can be used by the politician to share responsibility, and also to create involvement with the audience and to impart a sense of collectivity;

3. 'You' is used by the speaker to address parts of or the entire audience;

4. 'They' is used in political speeches to create an image of 'Other' and to divide people.

Furthermore, politicians have been shown to use the passive voice as a device to deflect blame, minimise emotional reactions, or to distance themselves from a particular issue. Grammatically, the passive voice is a sentence in which a noun is acted upon, permitting politicians to address an issue but not accept blame for it. For instance, when responding to the Abu Ghraib torture incident, George W. Bush said, "It's also important for the people of Iraq to know that in a democracy, everything is not perfect, that mistakes are made." He did not say "We made mistakes." (Ranker News: Politics, 2019)

In employing the passive voice when addressing the matter, Bush also distanced himself from the issue and effectively glossed over the incident. Charteris-Black (2005, p. 125) exemplified the extent to which voice allows politicians to distance or align themselves to a particular issue - depending, one presumes, on the political climate of the day - by presenting two statements by Bill Clinton: 
1. "All over the world people are being torn asunder by racial, ethnic and religious conflicts that fuel fanaticism and terror"

2. "Our purpose must be to bring together the world around freedom and democracy and peace and to oppose those who would tear it apart"

According to Beard (2000), the active voice requires an actor while a sentence employing the passive voice does not require that the actor be mentioned. In the first statement, the actors are inanimate (being "racial, ethnic, and religious conflicts") but the second statement is something else altogether, with the use of the active voice combined with the first person plural possessive pronoun 'our'. In this statement, the actors are animate and include Clinton himself. In both statements, although implicit, it is understood that Clinton is not responsible for the 'tearing asunder' and 'tearing apart', but is part of the 'bringing together' efforts.

\section{METHOD}

\section{PARTICIPANTS}

387 male and female undergraduate students of a public university in Malaysia took part in the present study. The participants were from various disciplines of the Arts and the Sciences, and comprised individuals of different races (Malay, Chinese, Indian, and East Malaysian ethnicity) within the age group of 19 to 25 years old. All participants were proficient in the English language (largely intermediate to higher intermediate levels). Purposive procedures were adhered to, taking into account the researcher's knowledge of the population of interest as well as the aim of the study.

\section{MATERIALS, DESIGN AND PROCEDURE}

The researcher designed two comprehensive questionnaires based on Fausey and Matlock's (2011) work. Participants were randomly assigned Version A or Version B. Both versions were about the conduct of Members of Parliament (MPs), unnamed and without party labels in order to avoid bias about actual politicians. 192 participants responded to Version A and 195 to Version B. Responses were collected via online and offline (printed) methods over a period of two consecutive weeks.

In the questionnaires, the MPs were described as doing negative or positive actions. Version A utilised the imperfective frame as well as the modal verb 'must' whereas Version B utilised the perfective frame as well as the modal verb 'have to'. The following table (Table 2) provides examples.

TABLE 2. Examples from Comprehensive Questionnaires: Versions A and B

\begin{tabular}{|c|c|}
\hline Version A & Version B \\
\hline Item 1 & $\underline{\text { Item } 1}$ \\
\hline $\begin{array}{l}\text { Person } A \text { is a Member of Parliament. He is up for re- } \\
\text { election. Last year, he was having an affair with his } \\
\text { assistant and was taking hush money from a } \\
\text { businessman. }\end{array}$ & $\begin{array}{l}\text { Person } A \text { is a Member of Parliament. He is up } \\
\text { for re-election. Last year, he had an affair with } \\
\text { his assistant and took hush money from a } \\
\text { businessman. }\end{array}$ \\
\hline a) Will this candidate be re-elected? & a) Will this candidate be re-elected? \\
\hline [Yes/No] & {$[\mathrm{Yes} / \mathrm{No}]$} \\
\hline b) How confident are you about this? & b) How confident are you about this? \\
\hline $\begin{array}{l}\text { [7-point scale, ranging from 'Extremely } \\
\text { Unconfident' to 'Extremely Confident'] }\end{array}$ & $\begin{array}{l}\text { [7-point scale, ranging from 'Extremely } \\
\text { Unconfident' to 'Extremely Confident'] }\end{array}$ \\
\hline c) Estimate the total amount of hush money: MYR & c) Estimate the total amount of hush money: \\
\hline
\end{tabular}


['Less than 1 million'/‘1 million to 5 million'/“More than 5 million']

$\underline{\text { Item } 5}$

Person E is a Member of Parliament. He is up for reelection. This year, his campaign includes this: "We must raise funds for the poor."

a) Will this candidate be re-elected?

[Yes/No]

b) How confident are you about this?

[7-point scale, ranging from 'Extremely Unconfident' to 'Extremely Confident']

c) Estimate the total amount of funds that he can potentially raise: MYR

['Less than 1 million'/‘ 1 million to 5 million'/‘More than 5 million']
MYR

['Less than 1 million'/'1 million to 5 million'/‘More than 5 million']

Item 5

Person E is a Member of Parliament. He is up for re-election. This year, his campaign includes this: "We have to raise funds for the poor."

a) Will this candidate be re-elected?

[Yes/No]

b) How confident are you about this?

[7-point scale, ranging from 'Extremely Unconfident' to 'Extremely Confident']

c) Estimate the total amount of funds that he can potentially raise: MYR

['Less than 1 million'/' 1 million to 5 million'/'More than 5 million']

For each version, the researcher did not repeat the MP labels (e.g., 'Person A') to avoid the probability of one item influencing a participant's judgment of another.

During data collection, the aim and context of the research were made clear to the students. It was also made clear to them that by responding to the questionnaire items, they were consenting to take part in the research. None of the participants received any monetary reward for their participation. The participants were assured that their identity would be kept confidential.

\section{RESULTS}

\section{Item 1}

Version A Person A is a Member of Parliament. He is up for re-election. Last year, he was having an affair with his assistant and was taking hush money from a businessman.

Version B Person A is a Member of Parliament. He is up for re-election. Last year, he had an affair with his assistant and took hush money from a businessman.

The following questions were posed after each item in both versions:

(a) Will this candidate be re-elected?

(b) How confident are you about this?

(c) Estimate the total amount of hush money: MYR

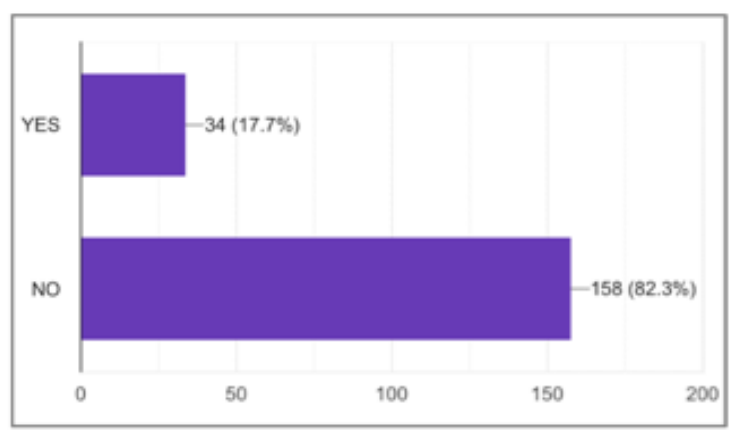

FIGURE 2. Version A I(a)

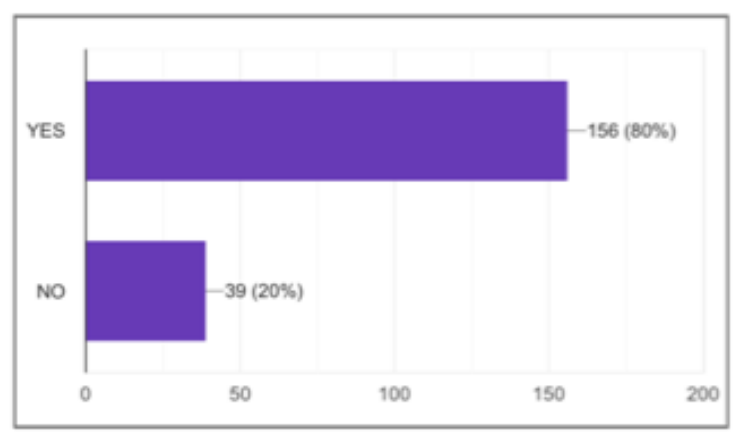

FIGURE 3. Version B 1(a) 


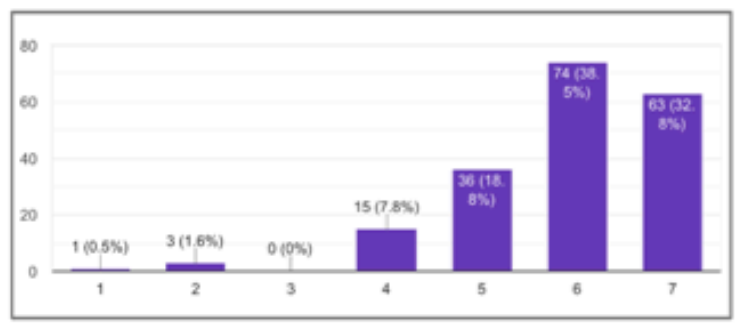

FIGURE 4. Version A 1(b)

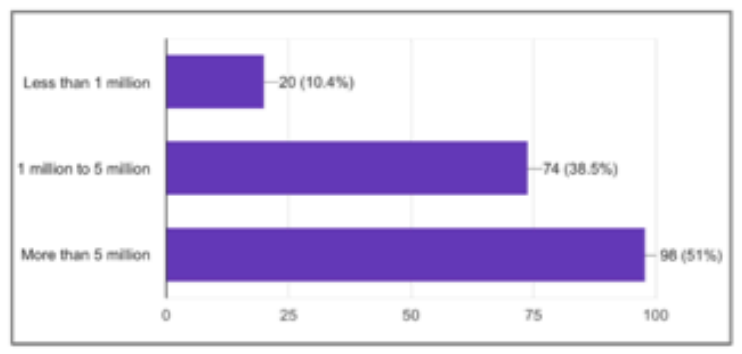

FIGURE 6. Version A 1(c)

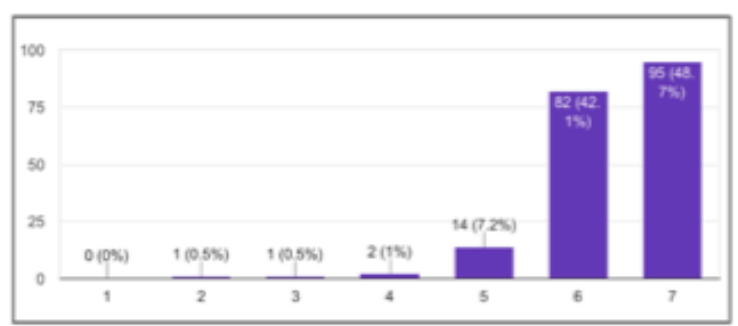

FIGURE 5. Version B 1(b)

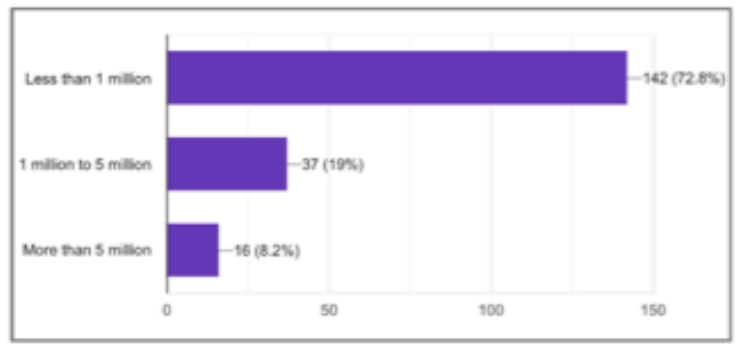

FIGURE 7. Version B I(c)

Referring to Item 1, the actions were of negative valence with Version A using the imperfective frame and Version $\mathrm{B}$, the perfective frame. A clear disparity is observed with 158 participants $(82.3 \%)$ responding negatively to the re-election of Person A (see Figure 2) whereas in comparison, only 39 participants $(20 \%)$ responded as such when posed with the perfective frame (Figure 3).

Secondly, the participants' confidence about their electability decision was analysed. Electability decisions were weighted by levels, based on a scale ranging from level 1 ('Extremely Unconfident') to level 7 ('Extremely Confident'). It was found that both groups, those who read Version A and those who read Version B, were largely strongly confident about their decisions. Figure 4 shows a total of 137 participants $(71.3 \%)$ opting for levels 6 and 7, while Figure 5 shows 177 participants (90.8\%) responding with levels 6 and 7.

Thirdly, grammatical form apparently influences the inferences that people make with respect to money. MYR estimates were higher when Person A was taking hush money versus when he took hush money. In Figure 6, of the group that read Version A (was taking), a total of 172 participants $(89.5 \%)$ selected ' 1 million to 5 million' and 'More than 5 million'. In contrast, of the group that read Version B (took), a total of 179 participants $(91.8 \%)$ selected ' 1 million to 5 million' and 'Less than 1 million' - $142(72.8 \%)$ of which selected 'Less than 1 million' (Figure 7).

\section{$\underline{\text { Item } 2}$}

Version A Person B is a Member of Parliament. He is up for re-election. Last year, he was demolishing buildings without permission and was receiving bribes from an overseas investor.

Version B Person B is a Member of Parliament. He is up for re-election. Last year, he demolished buildings without permission and received bribes from an overseas investor.

The following questions were posed after each item in both versions:

(a) Will this candidate be re-elected?

(b) How confident are you about this?

(c) Estimate the total amount of bribes: MYR 


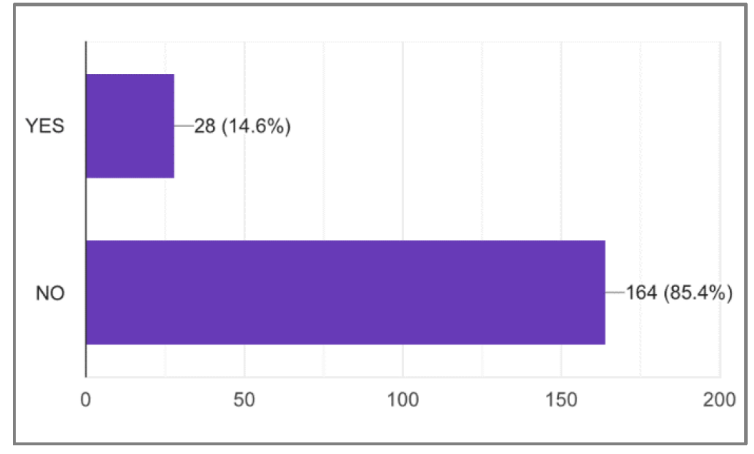

FIGURE 8. Version A 2(a)

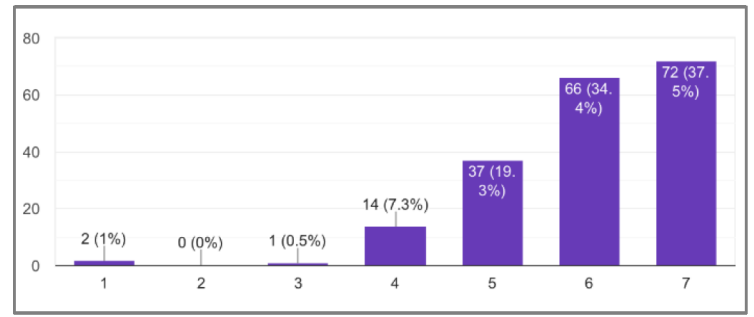

FIGURE 10. Version A 2(b)

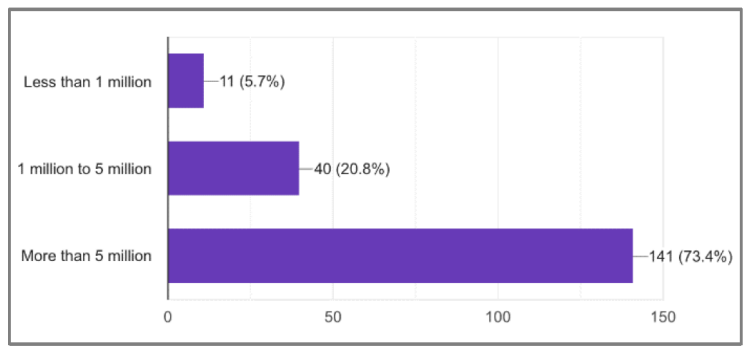

FIGURE 12. Version A 2(c)

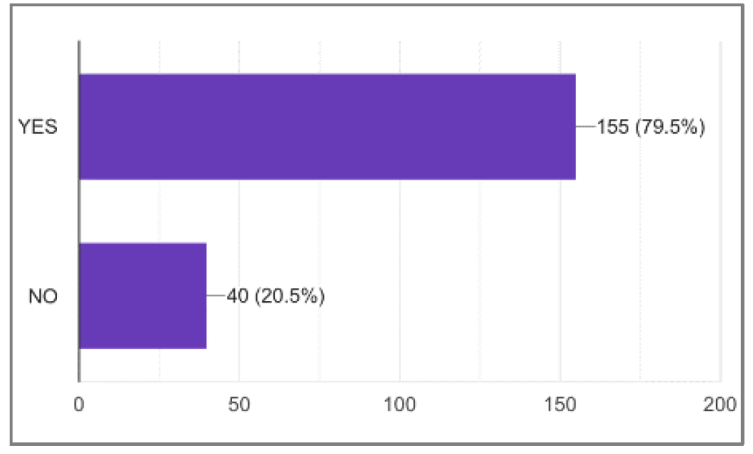

FIGURE 9. Version B 2(a)

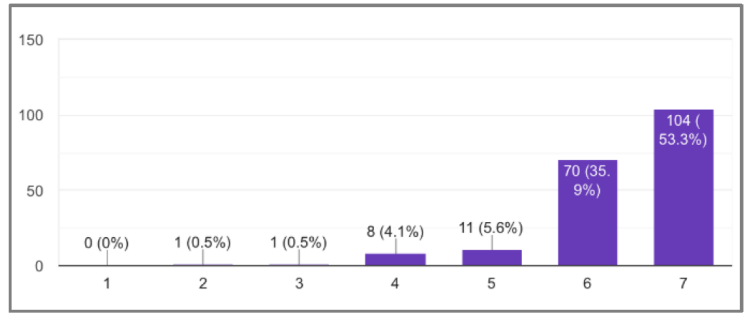

FIGURE 11. Version B 2(b)

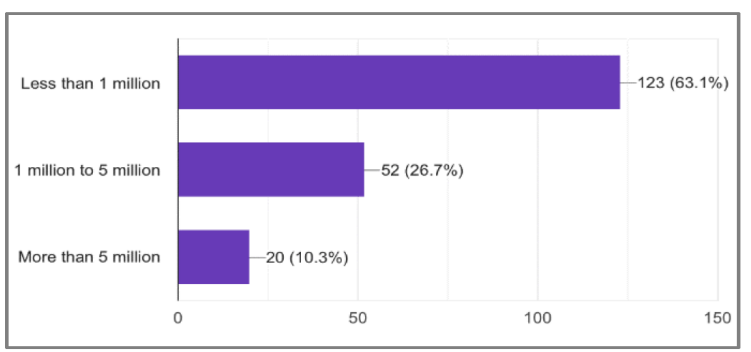

FIGURE 13. Version B 2(c)

Referring to Item 2, the actions were also of negative valence with Version A using the imperfective frame and Version $\mathrm{B}$, the perfective frame. A clear disparity is observed with 164 participants $(85.4 \%)$ responding 'No' to the re-election of Person B (see Figure 8) whereas in comparison, only 40 participants $(20.5 \%)$ responded similarly when posed with the perfective frame (Figure 9).

Secondly, regarding confidence levels, it was found that those who read Version A and those who read Version B were largely strongly confident about their decisions. Figure 10 shows a total of 138 participants $(71.9 \%)$ opting for levels 6 and 7, while Figure 11 shows 174 participants $(89.2 \%)$ responding with levels 6 and 7 .

Thirdly, MYR estimates were higher when Person B was receiving bribes versus when he received bribes. In Figure 12, of the group that read Version A (was receiving), a total of 181 participants $(94.2 \%)$ selected ' 1 million to 5 million' and 'More than 5 million'. In contrast, of the group that read Version B (received), a total of 175 participants $(89.8 \%)$ selected ' 1 million to 5 million' and 'Less than 1 million' - $123(63.1 \%)$ of which selected 'Less than 1 million' (Figure 13).

\section{Item 3}

Version A Person C is a Member of Parliament. He is up for re-election. Last year, he was extending roads to ease traffic congestion and was raising funds for disabled children. 
Version B Person C is a Member of Parliament. He is up for re-election. Last year, he extended roads to ease traffic congestion and raised funds for disabled children.

The following questions were posed after each item in both versions:

(a) Will this candidate be re-elected?

(b) How confident are you about this?

(c) Estimate the total amount of funds raised: MYR

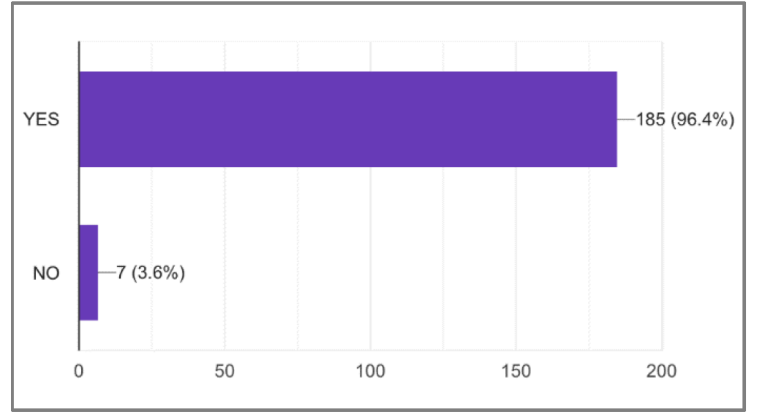

FIGURE 14. Version A 3(a)

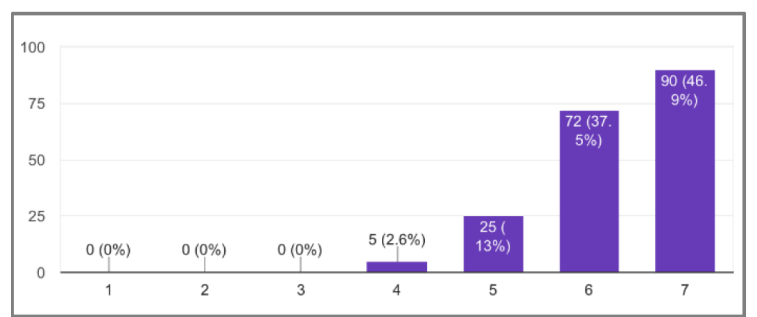

FIGURE 16. Version A 3(b)

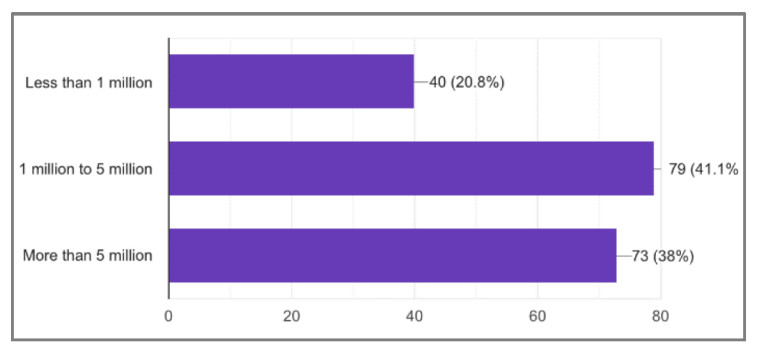

FIGURE 18. Version A 3(c)

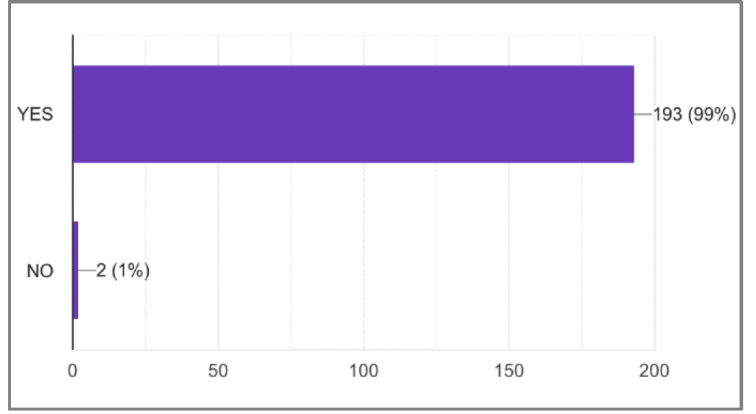

FIGURE 15. Version B 3(a)

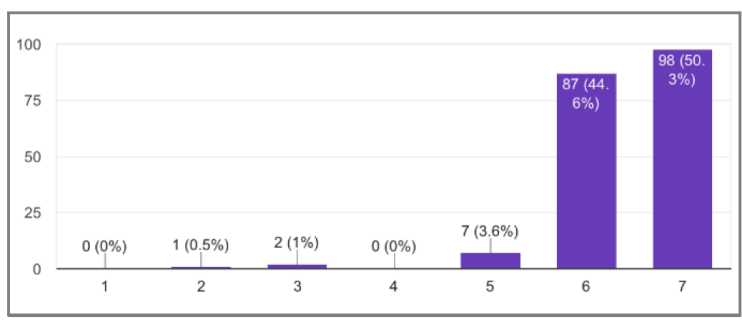

FIGURE 17. Version B 3(b)

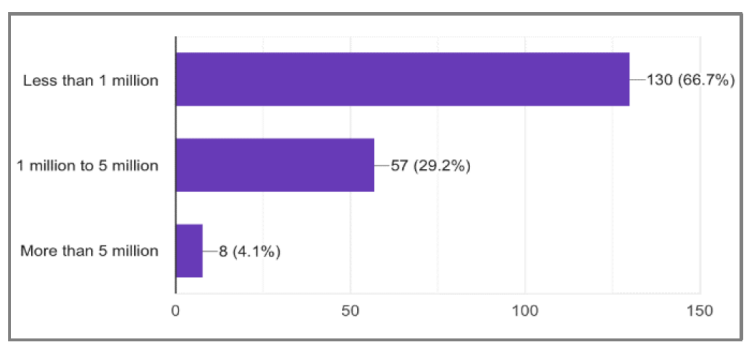

FIGURE 19. Version B 3(c)

Referring to Item 3, the actions were of positive valence with Version A employing the imperfective frame and Version B, the perfective frame. No substantial difference is observed with 185 participants $(96.4 \%)$ responding positively to the re-election of Person $\mathrm{C}$ (see Figure 14) and 193 participants (99\%) responding similarly when posed with the perfective frame (Figure 15).

Secondly, both groups - those who read Version A and those who read Version B largely demonstrated strong confidence about their decisions. Figure 16 shows a total of 162 participants $(84.4 \%)$ opting for levels 6 and 7, while Figure 17 shows 185 participants (94.9\%) responding with levels 6 and 7.

MYR estimates were higher when Person $\mathrm{C}$ was raising funds versus when he raised funds. In Figure 18, of the group that read Version A (was raising), a total of 152 participants (79.1\%) selected ' 1 million to 5 million' and 'More than 5 million'. In contrast, of the group 
that read Version B (raised), a total of 187 participants $(95.9 \%)$ selected ' 1 million to 5 million' and 'Less than 1 million' - 130 (66.7\%) of which selected 'Less than 1 million' (Figure 19).

\section{Item 4}

Version A Person D is a Member of Parliament. He is up for re-election. Last year, he was building schools in rural areas and was collecting donations for mental health research.

Version B Person D is a Member of Parliament. He is up for re-election. Last year, he built schools in rural areas and collected donations for mental health research.

The following questions were posed after each item in both versions:

(a) Will this candidate be re-elected?

(b) How confident are you about this?

(c) Estimate the total amount of donation money collected: MYR

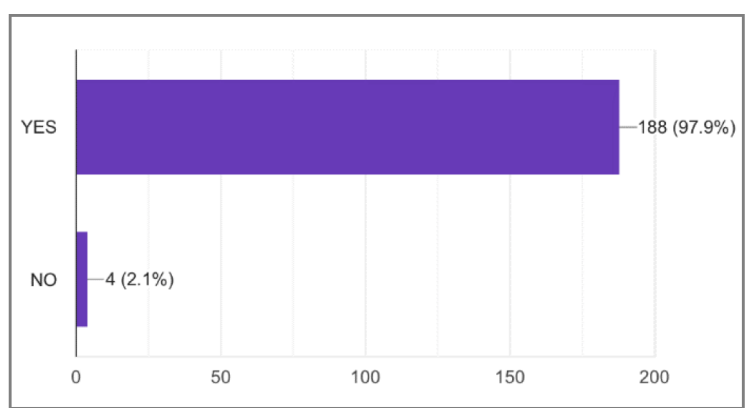

FIGURE 20. Version A 4(a)

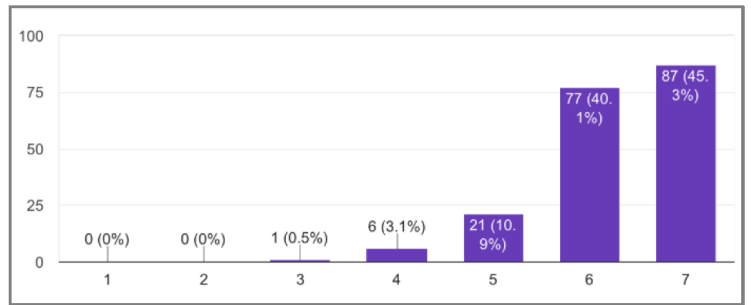

FIGURE 22. Version A 4(b)

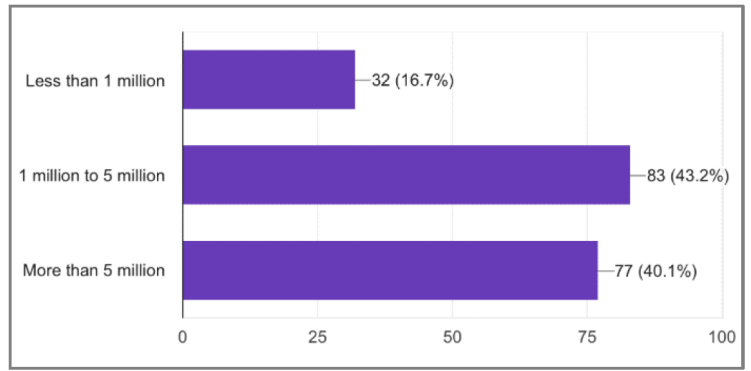

FIGURE 24. Version A 4(c)

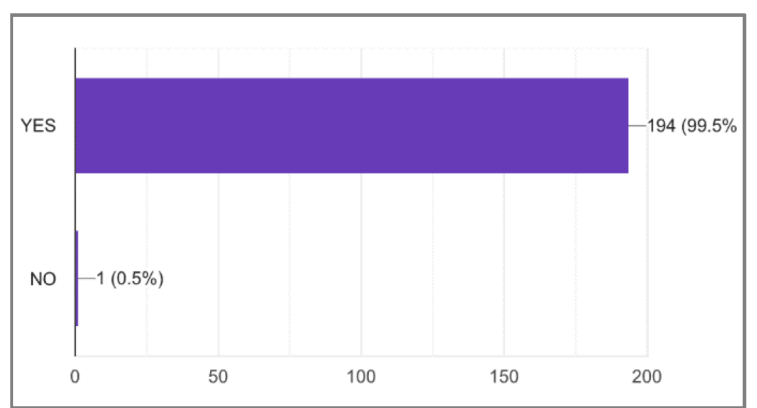

FIGURE 21. Version B 4(a)

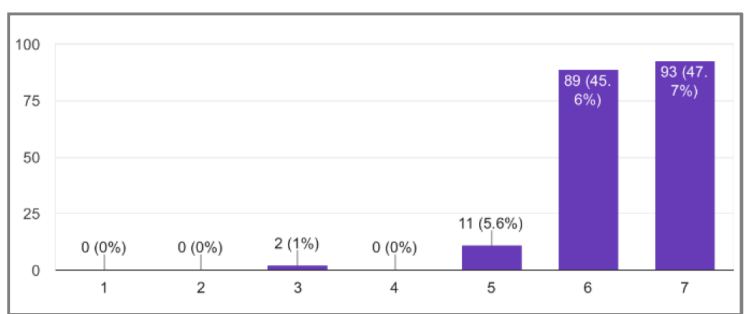

FIGURE 23. Version B 4(b)

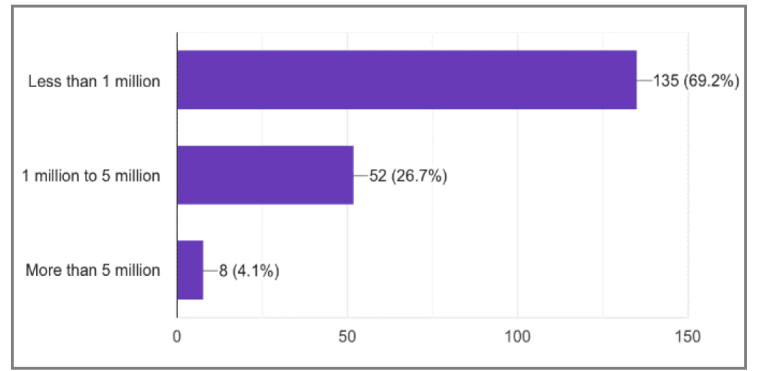

FIGURE 25. Version B 4(c)

With respect to Item 4 , the actions were also of positive valence. Version A employed the imperfective frame and Version B, the perfective frame. Again, no substantial difference is observed with 188 participants $(97.9 \%)$ responding positively to the re-election of Person 
D (Figure 20) and 194 participants (99.5\%) responding similarly when posed with the perfective frame (Figure 21).

Furthermore, both groups - those who read Version A and those who read Version B - largely demonstrated strong confidence about their decisions. Figure 22 shows a total of 164 participants $(85.4 \%)$ opting for levels 6 and 7. Figure 23, meanwhile, shows 182 participants (93.3\%) responding with the same levels.

MYR estimates were higher when Person D was collecting donations versus when he collected donations. In Figure 24, of the group that read Version A (was collecting), a total of 160 participants $(83.3 \%)$ selected ' 1 million to 5 million' and 'More than 5 million'. In contrast, of the group that read Version B (collected), a total of 187 participants $(95.9 \%)$ selected ' 1 million to 5 million' and 'Less than 1 million' - $135(69.2 \%)$ of which selected 'Less than 1 million' (Figure 25).

\section{$\underline{\text { Item } 5}$}

Version A Person E is a Member of Parliament. He is up for re-election. This year, his campaign includes this: "We must raise funds for the poor."

Version B Person E is a Member of Parliament. He is up for re-election. This year, his campaign includes this: "We have to raise funds for the poor."

The following questions were posed after each item in both versions:

(a) Will this candidate be re-elected?

(b) How confident are you about this?

(c) Estimate the total amount of funds that he can potentially raise: MYR

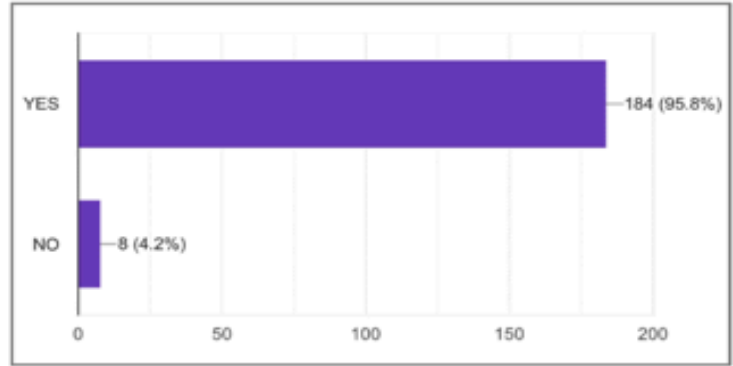

FIGURE 26. Version A 5(a)

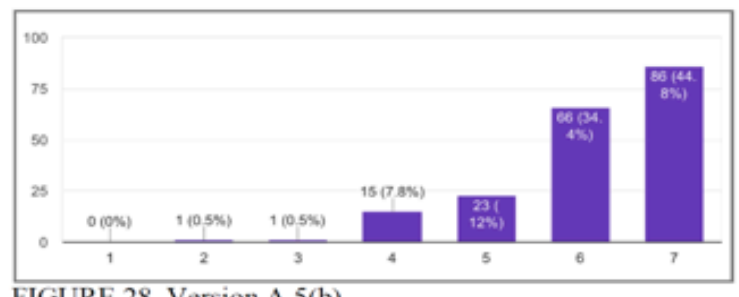

FIGURE 28. Version A 5(b)

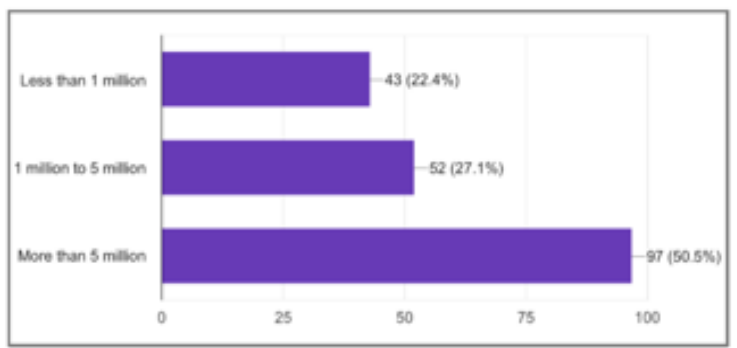

FIGURE 30. Version A 5(c)

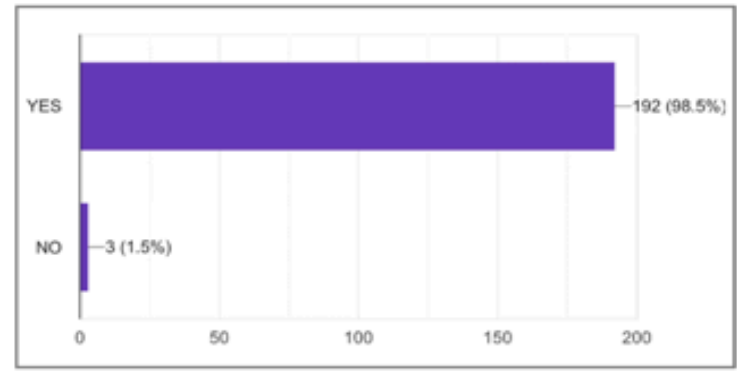

FIGURE 27. Version B 5(a)

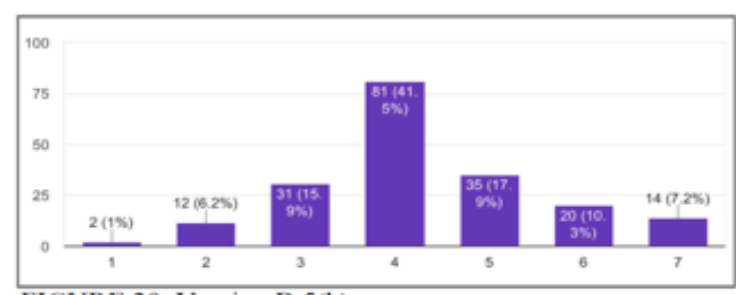

FIGURE 29. Version B 5(b)

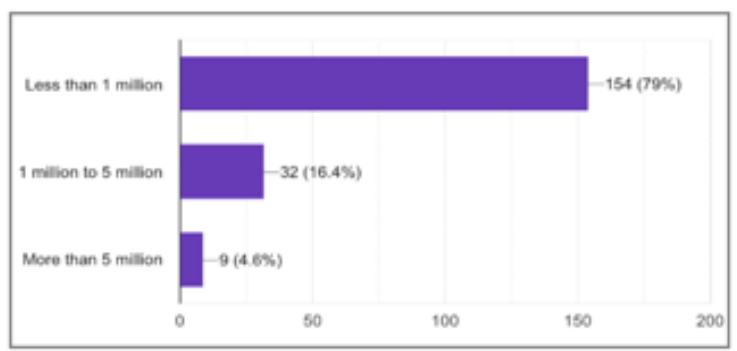

FIGURE 31. Version B 5(c) 
Referring to Item 5, Version A utilised the modal verb 'must' and Version B, the modal verb 'have to'. No clear disparity is observed; 184 participants $(95.8 \%)$ responded positively to the re-election of Person E (see Figure 26) and 192 participants (98.5\%) responded similarly when posed with the 'have to' frame (Figure 27).

The participants' confidence about their electability decision was also analysed. It was found that the groups differed in terms of their confidence levels. The group that read Version A largely opted for levels 6 and 7 (almost 80\% in total, see Figure 28) but the group that read Version B demonstrated less confidence, leaning more towards levels $3(15.9 \%), 4$ $(41.5 \%)$ and 5 (17.9\%) (Figure 29).

MYR estimates were also higher when must raise funds was used versus when have to raise funds was used. In Figure 30, of the group that read Version A (must), a total of 149 participants (77.6\%) selected ' 1 million to 5 million' and 'More than 5 million'. In contrast, of the group that read Version B (have to), a total of 186 participants (95.4\%) selected ' 1 million to 5 million' and 'Less than 1 million' - 154 (79\%) of which selected 'Less than 1 million' (Figure 31).

\section{$\underline{\text { Item } 6}$}

Version A Person F is a Member of Parliament. He is up for re-election. This year, his campaign includes this: "We must collect donations for the unfortunate."

Version B Person F is a Member of Parliament. He is up for re-election. This year, his campaign includes this: "We have to collect donations for the unfortunate."

The following questions were posed after each item in both versions:

(a) Will this candidate be re-elected?

(b) How confident are you about this?

(c) Estimate the total amount of donation money that he can potentially collect: MYR

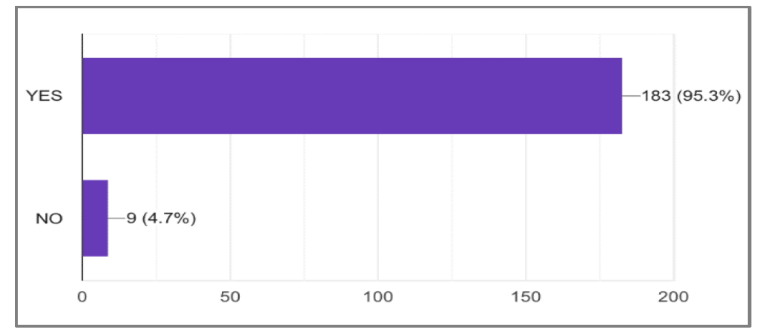

FIGURE 32. Version A 6(a)

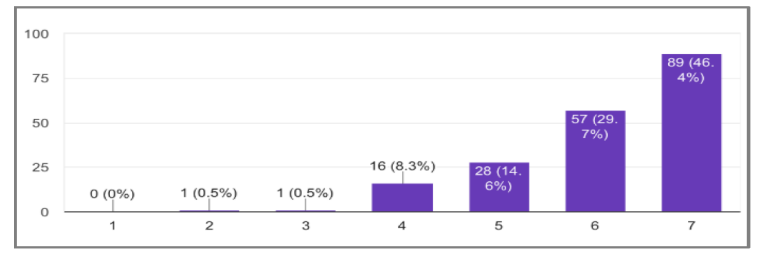

FIGURE 34. Version A 6(b)

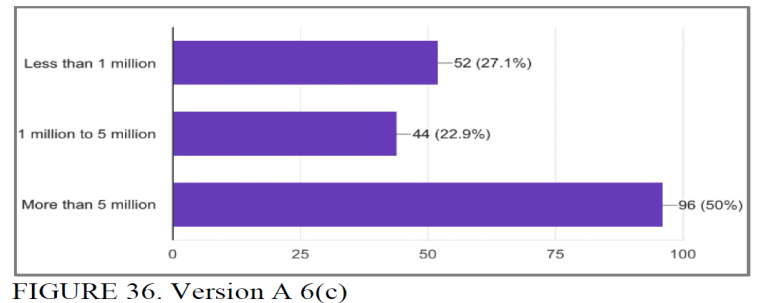

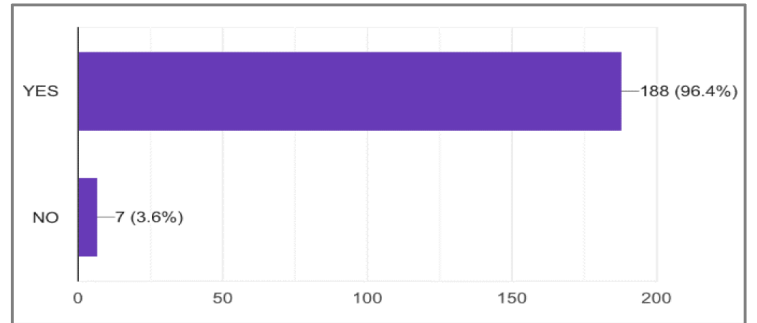

FIGURE 33. Version B 6(a)

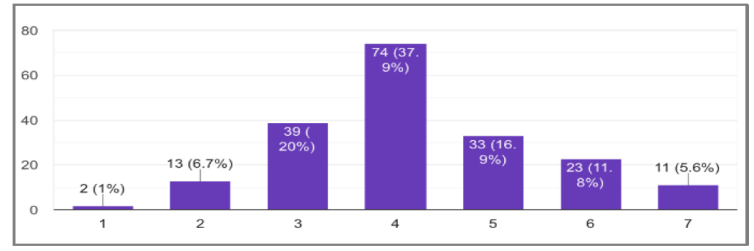

FIGURE 35. Version B 6(b)

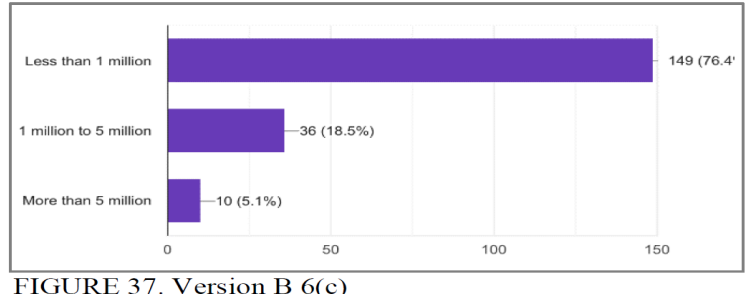


With respect to Item 6, in which Version A employed the modal verb 'must' and Version B the modal verb 'have to', no substantial difference is observed. 183 participants $(95.3 \%)$ responded positively to the re-election of Person F (see Figure 32) and 188 participants (96.4\%) responded similarly when posed with the 'have to' frame (Figure 33).

Additionally, it was found that the groups again differed in terms of their confidence levels. The group that read Version A largely opted for levels 6 and 7 (about 76\% in total, see Figure 34) but the group that read Version B demonstrated less confidence, leaning more towards levels $3(20 \%), 4(37.9 \%)$ and 5 (16.9\%) (Figure 35).

MYR estimates were also higher when must collect donations was used versus when have to collect donations was used. In Figure 36, of the group that read Version A (must), a total of 140 participants $(72.9 \%)$ selected ' 1 million to 5 million' and 'More than 5 million'. In contrast, of the group that read Version B (have to), a total of 185 participants $(94.9 \%)$ selected ' 1 million to 5 million' and 'Less than 1 million' - 149 (76.4\%) of which selected 'Less than 1 million' (Figure 37).

\section{DISCUSSION AND CONCLUSION}

The present study suggests that grammar can influence electability. Items 1 and 2 were of negative valence and a slight alteration in the grammatical form of the descriptions resulted in substantial disparities that cannot be ignored. When posed with the imperfective frame, most of the participants responded negatively to the re-election of the candidate. Conversely, those posed with the perfective frame mostly responded positively to the re-election of the candidate. In both cases, the participants were largely strongly confident about their decisions. Interestingly, the participants also clearly selected higher MYR estimates for hush money and bribes when the actions were described using the imperfective frame.

However, the participants were to a great degree insensitive to grammatical alteration when reasoning about a candidate's past positive actions. Items 3 and 4 were of positive valence and despite changes in grammatical information, an overwhelming majority from both groups consistently responded positively to the re-election of the candidate. In both cases, they were also largely strongly confident about their decisions. It is worthy of note, however, that those who read Version A (imperfective frame) opted for higher MYR estimates for funds and donations than those who read Version B (perfective frame).

The results are largely in tandem with Fausey and Matlock's (2011) findings relating to grammar and voting behaviour. Essentially, it appears that framing can affect reasoning. As with Matlock et al.'s (2012) vehicle collisions study, imperfective framing does indeed seem to trigger the encoding of more action per situation than perfective framing. Basically, people tend to replay in their mind richer and more vivid action details with imperfective framing, which might explain why the participants of the present study responded the way they did - especially with regards to their MYR estimates. It is particularly interesting that despite being insensitive to grammatical alteration when reasoning about past positive actions, those who read Version A still chose higher MYR estimates than those who read Version B, suggesting that the former group experienced richer mental encoding and thus amplified in greater volume the amount of funds raised and donation money collected.

Furthermore, as put forth by Matlock (2012), an event is often conceptualised as ongoing with the use of the imperfective and conceptualised as completed with the use of the perfective. Similarly, this might explain the findings of the present study, whereby the Version A group construed the described actions (negative and positive) as ongoing events, more so than the Version B group.

This study also examined modality. Items 5 and 6 were framed using modal verbs; Version A employed 'must' while Version B utilised 'have to'. The items were of positive 
valence. In all instances, most of the participants responded positively to the re-election of the candidate. Their confidence about their decisions, however, varied. The Version A group consistently demonstrated strong confidence levels while the Version B participants tended to be more neutral and less sure about their decisions. Additionally, the Version A group selected higher MYR estimates for funds and donations than the Version B group. These findings suggest that the modal verb 'must' renders more impact than 'have to' and that generally, more favourable responses can be expected with the use of 'must' in political communication. More specifically, these findings suggest that people respond less positively to what they perceive as impersonal ideas. Grammatically, 'must' and 'have to' are used in expressions of obligation and the difference between them is better described as emotional rather than structural. Commonly, 'must' implies that the obligation comes directly from the speaker while 'have to' implies that the obligation has an external source; this delivers the sense or notion that 'must' expresses the speaker's feelings and is thus more personal, whereas 'have to' expresses a more impersonal and detached idea.

This study involved university students of 19 to 25 years old - essentially, individuals who were either already of voting age or will be so in the next Malaysian General Election. Fundamentally, the study has shown that grammar can influence electability as people do appear to be sensitive to subtle linguistic details when judging political candidates. The only exception is when they reasoned about a candidate's past positive actions; their insensitivity at this juncture could perhaps be explained best by the possibility that mental representations driven by linguistic constructs are relatively more robust for negative events. In addition, it is worth noting that while the imperfective and perfective aspects are understudied, the findings on modality are novel and suggest that construals can be affected by the degree of "emotional value" that a modal verb holds. Additionally, referring to a possible limitation, although it is unlikely that the English language ability of the study's participants could have influenced the findings (as the questionnaire constructs were essentially uncomplicated as well as straightforward, and the participants were largely of intermediate to higher intermediate proficiencies), the researcher still opts for a more cautious position and recommends that future research in this direction should ideally exert even more stringent control for language ability.

Further research is vital as political communication is a constant, and insight into the power of grammar is not only likely to improve political communication but also affords us a fuller understanding of how language can shape voting patterns. It is recommended that future studies examine a wider range of grammatical features and cover contexts external of the American or Western sphere.

\section{REFERENCES}

Al-Rikaby, A., Tengku Mahadi, T.S. \& Tan, D.A.L. (2018). Analyzing the political uses of figures of speech in non-state leaders' rhetorical titles: Case studies of Al-Qa'ida and ISIS. Pertanika Journal of Social Sciences \& Humanities. 26(T): Thematic Edition, 299-311.

Alavidze, M. (2017). The use of pronouns in political discourse. International Journal of Arts \& Sciences. 9(4), 349-356.

Allen, W. (2007). Australian political discourse: Pronominal choice in campaign speeches. In Mary Laughren \& Ilana Mushin (Eds.), Selected papers from the 2006 Conference of the Australian Linguistic Society. Available at: https://core.ac.uk/download/pdf/14985479.pdf

Beard, A. (2000). The language of politics. London: Routledge. 
Bernama (April 2018). Electoral agents the best monitors for GE14. Available at: https://www.nst.com.my/news/politics/2018/04/352884/electoral-agents-bestmonitors-ge14

Bramley, N. R. (2001). Pronouns of politics: The use of pronouns in the construction of 'self' and 'other' in political interviews. (Unpublished Doctoral Thesis). Australian National University, Australia.

Charteris-Black, J. (2005). Politicians and rhetoric: The persuasive power of metaphor. New York: Palgrave Macmillan.

Fausey, C. M. \& Matlock, T. (2011). Can grammar win elections? Political Psychology. $32(4), 563-574$.

Fountaine, S. (2017). What's not to like?: A qualitative study of young women politicians' self-framing on Twitter. Journal of Public Relations Research. 29(5), 219-237.

Hanks, W.F. (1996). Language and communicative practices (Critical essays in anthropology 1). Colorado: Westview Press.

Imre, A. (2017). A logical approach to modal verbs 'can' and 'could'. Acta Universitatis Sapientiae, Philologica. 9(2), 125-144.

Kakzhanova, F.A. (2013). What modals are: Modal verbs, modal words, and auxiliary modals. European Researcher. 61(10-2), 2530-2535.

Kasim, A. \& Mohd Sani, M.A. (2016). The 2013 general elections in Malaysia: An analysis of online news portals. Kasetsart Journal of Social Sciences, 37, 119-125.

Lakoff, G. (2002). Moral politics: How liberals and conservatives think. Chicago: University of Chicago Press.

Lakoff, G. (2004). Don't think of an elephant!: Know your values and frame the debate - The essential guide for progressives. Vermont: Chelsea Green Publishing.

Lakoff, G. (2016). Understanding Trump. Available at: https://georgelakoff.com/2016/07/23/understanding-trump-2/

Lakoff, G. \& Johnson, M. (1999). Philosophy in the Flesh: The Embodied Mind and its Challenge to Western thought. New York: Basic Books.

Madden, C.J. \& Zwaan, R.A. (2003). How does verb aspect constrain event representations. Memory \& Cognition, 31(5), 663-672.

Mannetti, L., Brizi, A., Giacomantonio, M. \& Higgins, E.T. (2013). Framing political messages to fit the audience's regulatory orientation: How to improve the efficacy of the same message content. PLOS ONE. 8(10), e 77040.

Matlock, T. (2012). Framing political messages with grammar and metaphor. American Scientist. 100(6), 478-483.

Matlock, T., Sparks, D., Matthews, J.L., Hunter, J. \& Huette, S. (2012). Smashing new results on aspectual framing: How people describe car accidents. Studies in Language, 36, 700-721.

McNeil, B.J., Pauker, S.G., Sox, H.C. Jr. \& Tversky, A. (1982). On the elicitation of preferences for alternative therapies. New England Journal of Medicine. 306, 12591262.

Ostwald, K. (2017). Malaysia's electoral process: The methods and costs of perpetuating UMNO rule. Available at https://papers.ssrn.com/sol3/papers.cfm?abstract id=3048551

Palmer, F.R. (1990). Modality and the English modals (Second Edition). New York \& London: Routledge.

Pluwak, A. (2011). The linguistic aspect of strategic framing in modern political campaigns. Cognitive Studies. 11, 307-319. 
Ranker News: Politics (2019). Every time a major politician used the passive voice to deflect blame. Available at: https://www.ranker.com/list/times-politicians-used-passivevoice-to-deflect-blame/ranker-news

Thibodeau, P.H. \& Boroditsky, L. (2011). Metaphors we think with: The role of metaphor in reasoning. PLOS ONE. 6(2), e16782.

Tversky, A. \& Kahneman, D. (1986). Rational choice and the framing of decisions. The Journal of Business. 59(4), S251-S278.

\section{ABOUT THE AUTHOR}

Debbita Tan Ai Lin (Dr.) serves as Senior Lecturer at the School of Languages, Literacies and Translation, Universiti Sains Malaysia. She is keen on interdisciplinary research and her areas of interest include English language and media studies, applied linguistics and more recently, the relationship between psychology and linguistic nuances. Her full profile and publications can be accessed at https://www.researchgate.net/profile/Debbita_Tan/publications 